\title{
Beneficial Effects of Potassium on Growth, Water Relations, Mineral Accumulation and Oxidative Damage of Beta vulgaris in Sodic-alkaline Condition
}

\author{
Liyun Liu ${ }^{1}$, Hany A. El-Shemy ${ }^{2}$ and Hirofumi Saneoka ${ }^{*}$ \\ ${ }^{1}$ Graduate School of Biosphere Science, Hiroshima University, 1-4-4 Kagamiyama, Higashi-Hiroshima, 739-8528, Japan \\ ${ }^{2}$ Cairo University Research Park, Faculty of Agriculture, Cairo University, 12613 Giza, Egypt \\ *For correspondence: saneoka@hiroshima-u.ac.jp
}

\begin{abstract}
Potassium $\left(\mathrm{K}^{+}\right)$plays a vital role for plant growth and therefore the amount of $\mathrm{K}^{+}$seems to be a key of plant development. Therefore, this study investigated whether the sodic-alkalinity tolerance of Swiss chard (Beta vulgaris L. subsp. cicla) could be increased, via greater water uptake, higher concentrations of mineral elements and higher antioxidant enzyme activities in sodic-alkaline stress conditions with $\mathrm{K}^{+}$supplementation. Forty seven day old uniform seedlings were pre-treated in hydroponic medium with or without $\mathrm{K}^{+}$for 7 days, and then treated in non-alkaline or alkaline conditions for 9 days. The absence of $\mathrm{K}^{+}$somewhat intensified the effect of alkalinity on reducing the growth of Swiss chard, the total dry weight (DW) was reduced by $34 \%$ in plants treated in sodic-alkaline conditions without $\mathrm{K}^{+}$when compared with plants with $\mathrm{K}^{+}$. Relative water content (RWC) of leaves was increased by $10 \%$ by $\mathrm{K}^{+}$supplementation in sodic-alkaline conditions. Additionally, the osmotic adjustment was retorted; the contents of $\mathrm{K}^{+}, \mathrm{Cl}^{-}, \mathrm{BO}_{3}^{-}, \mathrm{Fe}^{3+}$ and $\mathrm{Mn}^{2+}$, and the activities of catalase, guaiacol peroxidase, and glutathione reductase were increased. On other hand, $\mathrm{K}^{+}$supplementation in sodic-alkaline conditions helped to maintain guaiacol peroxidase activity similar to that of control plants, and reduced malondialdehyde content when compared with plants treated in sodic-alkaline conditions without $\mathrm{K}^{+}$. In conclusion, the $\mathrm{K}^{+}$supplementation resulted in favorable changes in plants with higher micronutrient contents and a reduction of oxidative damage induced by sodicalkalinity in Swiss chard. (C) 2017 Friends Science Publishers
\end{abstract}

Keywords: Micronutrients; Osmotic adjustment; Potassium; Sodic-alkalinity; Swiss chard; Reactive oxygen species

\section{Introduction}

Potassium $\left(\mathrm{K}^{+}\right)$is major inorganic constituent of living cells and required in large amounts for plant growth and development, being taken from soil then translocated to various organs for many processes in plant cells (Kanai et al., 2011; Chérel et al., 2014). Plants need a high content of $\mathrm{K}^{+}$for specific functions in the cytoplasm and $90 \%$ is localized in vacuoles (Wakeel et al., 2011). However, in conditions with high contents of $\mathrm{Na}^{+}, \mathrm{Na}^{+}$reduce the activity of $\mathrm{K}^{+}$, and also compete with $\mathrm{K}^{+}$for uptake sites at the plasma membrane (Shabala and Cuin, 2007). When positively charged $\mathrm{Na}^{+}$crosses the plasma membrane, significant membrane depolarization makes passive $\mathrm{K}^{+}$ uptake through inward-rectifying $\mathrm{K}^{+}$channels impossible, and $\mathrm{K}^{+}$leakage increases through depolarization-activated outward-rectifying $\mathrm{K}^{+}$channels (Shabala and Cuin, 2007). For particular plant species of the Chenopodiaceae, $\mathrm{K}^{+}$ localized in vacuoles was substituted by $\mathrm{Na}^{+}$to a high degree, and plants grow on soils with high K-fixing capacity have more potential for this substitution (Subbarao et al., 2000; Wakeel et al., 2010), and supplementation of $\mathrm{Na}^{+}$in reduced amounts eliminated $\mathrm{K}^{+}$-deficient symptoms in conditions of limited $\mathrm{K}^{+}$supply (Wakeel et al., 2011). Therefore, some species of Chenopodiaceae showed particularly strong stimulation by low $\mathrm{Na}^{+}$application in either low- or high-K conditions (EI-Sheikh et al., 1967; Subbarao et al., 2003).

Many saline soils are also sodic-alkaline due to the presence of $\mathrm{NaHCO}_{3}$ and $\mathrm{Na}_{2} \mathrm{CO}_{3}$, which resulted in high soil $\mathrm{pH}$, usually greater than 8.5 (Lyubimova et al., 2009; Bui, 2013). Sodic-alkalinity is more deleterious to plant growth than salinity alone, and results in laboratory-bred NaCl-tolerant cultivars failing to achieve good yield in field conditions (Nishiuchi et al., 2010; Bui, 2013). Overproduced reactive oxygen species (ROS) can activate plasma membrane $\mathrm{K}^{+}$and $\mathrm{Ca}^{2+}$ permeable conductance, which mediate $\mathrm{K}^{+}$efflux and $\mathrm{Ca}^{2+}$ influx, respectively, resulted in a concomitant elevation of cytosolic $\mathrm{Ca}^{2+}$ activity and $\mathrm{K}^{+}$loss (Demidchik et al., 2003; Demidchik et al., 2007). Alongside toxic $\mathrm{Na}^{+}$influx, cytosolic ionic homeostasis is seriously impaired, and cellular tissue damage occurs via a number of destructive processes following a rise in ROS levels (Ashraf, 2009; 
Velarde-Buendía et al., 2012). The most abundant types of ROS in plants are hydrogen peroxide $\left(\mathrm{H}_{2} \mathrm{O}_{2}\right)$, superoxide radical, and hydroxyl radical. To detoxify ROS, plant cells and their organelles employ both enzymatic and non-enzymatic mechanisms (Zepeda-Jazo et al., 2011). Enzymatic antioxidants include superoxide dismutase (SOD; EC 1.15.1.1), catalase (CAT; EC 1.11.1.6), guaiacol peroxidase (GPX; EC 1.11.1.7), ascorbate peroxidase (APX; EC 1.11.1.1), and glutathione reductase (GR; EC 1.6.4.2) (Gill and Tutejia, 2010). APX, followed by CAT, is the key enzyme in detoxifying $\mathrm{H}_{2} \mathrm{O}_{2}$ (Ashraf, 2009). It plays a vital role in plant defense against oxidative stress (Ashraf, 2009; Hernandez et al., 2012). GPX not only scavenges $\mathrm{H}_{2} \mathrm{O}_{2}$, but also involves in the biosynthesis of cell wall components and tissue lignification (Cavalcanti et al., 2004). The common nonenzymatic antioxidants are glutathione, ascorbate, carotenoids, phenolic compounds and non-protein amino acids (Ashraf, 2009; Gill and Tuteja, 2010).

Swiss chard (Beta vulgaris L. subsp. cicla) is a foliage vegetable closely related to beets with a large leaf blade, thicker petiole, and no root enlargement (Welbaum, 2015). The leaf of Swiss chard contains nutritionally significant contents of magnesium, calcium and phosphorus, and has potential to protect humans against several chronic diseases such as diabetes (Pyo et al., 2004; Maynard and Hochmuth, 2007; Sacan and Yanardag, 2010). However, the growth of Swiss chard is severely suppressed by alkaline conditions owing to serious impairment of intracellular $\mathrm{Na}^{+}$ and $\mathrm{K}^{+}$homeostasis, and serious $\mathrm{K}^{+}$starvation in tissues (Liu et al., 2013).

As mentioned above, although sodic-alkaline conditions and $\mathrm{K}^{+}$starvation have been studied extensively, impact of the combination of these conditions on plants was not examined. The main objective of this study is to examine the influence of $\mathrm{K}^{+}$on the responses of Swiss chard to sodic-alkaline constraints, and to explore differences in physiological parameters in Swiss chard seedlings subjected to sodic-alkaline conditions with or without $\mathrm{K}^{+}$ supplementation.

\section{Materials and Methods}

\section{Plant Material and Treatment Conditions}

The description of Swiss chard (Beta vulgaris L. subsp. cicla) seeds used in this study was the same as described by Liu et al. (2013). The seeds were sown in a plastic seed bed (96 wells per bed) and irrigated with tap water in a greenhouse of the Faculty of Applied Biological Sciences, Hiroshima University, Japan. Forty five days after sowing, uniform seedlings that have shed their cotyledons from the mother plants were transferred to deionized water for discarding nutrients on the root surface. After two days, seedlings were transplanted to water culture solution with or without $\mathrm{K}^{+}$for 1 week $\left(\mathrm{K}^{+}\right.$pre-treatment). The nutrient medium with $\mathrm{K}^{+}$contained the following macronutrients: $0.6 \mathrm{~m} M \mathrm{NH}_{4} \mathrm{NO}_{3}, 0.2 \mathrm{~m} M \mathrm{NH}_{4} \mathrm{H}_{2} \mathrm{PO}_{4}$, $0.34 \mathrm{~m} M \mathrm{~K}_{2} \mathrm{SO}_{4}, 0.34 \mathrm{~m} M \mathrm{KCl}, 0.38 \mathrm{~m} M \mathrm{Ca}\left(\mathrm{NO}_{3}\right)_{2}$, and $0.2 \mathrm{mM} \mathrm{MgSO}_{4}$, and the following micronutrients: $4 \mu M$ $\mathrm{MnCl}_{2} \cdot 4 \mathrm{H}_{2} \mathrm{O}, 8 \mu M \mathrm{H}_{3} \mathrm{BO}_{3}, 0.12 \mu M \mathrm{CuSO}_{4} \cdot 5 \mathrm{H}_{2} \mathrm{O}, 0.3$ $\mu M \mathrm{ZnSO}_{4} \cdot 7 \mathrm{H}_{2} \mathrm{O}, 0.07 \mu M \mathrm{MoO}_{3}$, and $20 \mu M$ Fe-EDTA. For no $\mathrm{K}^{+}$treatment, $\mathrm{K}_{2} \mathrm{SO}_{4}$ and $\mathrm{KCl}$ were omitted from the nutrient medium. $70 \mathrm{~L}$ plastic containers (12 plants for each container) were maintained under natural sunlight conditions of the greenhouse.

After $\mathrm{K}^{+}$pre-treatment, the seedlings were transplanted to $20 \mathrm{~L}$ plastic containers (six plants for each container) filled with nutrient mediums as mentioned above, and treated by both sodic-alkalinity and non-sodic control, respectively (for 9 days). All 4 treatments were as follow: 0 $\mathrm{m} M \mathrm{~K}, 2 \mathrm{~m} M \mathrm{~K}$, Alkalinity $+0 \mathrm{~m} M \mathrm{~K}$, and Alkalinity $+2 \mathrm{~m} M$ $\mathrm{K}$. The nutrient solutions of $2 \mathrm{~m} M \mathrm{~K}$ and Alkalinity $+2 \mathrm{mM}$ $\mathrm{K}$ treatments contained the same micronutrients and macronutrients with $\mathrm{K}^{+}$-pretreatment except for $\mathrm{K}^{+}$, which was simulated by adding $0.68 \mathrm{mM} \mathrm{K} \mathrm{K}_{2} \mathrm{SO}_{4}$ and $0.68 \mathrm{mM}$ $\mathrm{KCl}$. For $0 \mathrm{~m} M \mathrm{~K}$ and Alkalinity $+0 \mathrm{~m} M \mathrm{~K}$ treatments, the omission of $\mathrm{K}_{2} \mathrm{SO}_{4}$ and $\mathrm{KCl}$ from the nutrient medium was continued. The sodic-alkalinity was simulated by a mixture of $\mathrm{NaHCO}_{3}$ and $\mathrm{Na}_{2} \mathrm{CO}_{3}\left(\mathrm{NaHCO}_{3}: \mathrm{Na}_{2} \mathrm{CO}_{3}=9: 1\right.$ molar ratio) as described by our previous study (Liu et al., 2013). The electrical conductivity (EC) of the nutrient medium was gradually increased from $186.8 \mathrm{mS} \mathrm{m}^{-1}$ to $340 \mathrm{mS} \mathrm{m}$ to $493 \mathrm{mS} \mathrm{m}^{-1}$ for Alkalinity $+2 \mathrm{mM} \mathrm{K}$ treatment, while from $208 \mathrm{mS} \mathrm{m}^{-1}$ to $354 \mathrm{mS} \mathrm{m}^{-1}$ to $506 \mathrm{mS} \mathrm{m}^{-1}$ for Alkalinity +0 $\mathrm{m} M \mathrm{~K}$ treatment, through the gradual increase of $\mathrm{Na}^{+}$ content from $20 \mathrm{~m} M$ to $40 \mathrm{~m} M$ to $60 \mathrm{~m} M$ every 3 days. $1 M$ $\mathrm{NaOH}$ was used to adjust the $\mathrm{pH}(5.5-6.0)$ of the basal nutrient solution, which was used for $0 \mathrm{~m} M \mathrm{~K}$ and $2 \mathrm{~m} M \mathrm{~K}$ treatments. For the Alkalinity $+0 \mathrm{~m} M$ and Alkalinity $+2 \mathrm{~m} M$ treatments, the $\mathrm{pH}$ ranges of the nutrient medium were increased to 8.8-9.1 after adding $\mathrm{NaHCO}_{3}$ and $\mathrm{Na}_{2} \mathrm{CO}_{3}$ to the basal nutrient solution. The nutrient medium was renewed every 3 days. The pots were still maintained under natural sunlight condition in the greenhouse. The average temperature was $23^{\circ} \mathrm{C}$, and the average of relative humidity was $58 \%$ during treatment period.

\section{Physiological Parameters}

At the end of the treatment period, plants were carefully separated into leaf blade, petiole and root, and each plant part was weighted and freeze-dried. The freeze-dried samples were used for the estimation of dry weight (DW), and young leaf blades were sampled for analyses. The relative water content (RWC) was measured as described by Turner (1981). The saturated osmotic potential $\left(\Psi_{\pi}^{100}\right)$ was calculated using the following equation (Saneoka et al., 1995): $\Psi_{\pi}^{100}=$ (osmotic potential [RWC - apoplastic water content $] /[1.0$ - apoplastic water content]. The apoplastic water content is assumed as 0.15 , and osmotic potential of the cell sap was measured by Wescor 5500 vapor pressure osmometer (Wescor Inc., Logan, UT, USA). 
For mineral analysis, young leaf blades were freezedried and then ground into fine powder. Sample digestion for cations, and measurements of the $\mathrm{Na}^{+}$and $\mathrm{K}^{+}$contents were conducted as descripted by Liu et al. (2013), $\mathrm{Mg}^{2+}$ and $\mathrm{Ca}^{2+}$ contents were determined as described by Saneoka et al. (1999), and $\mathrm{BO}_{3}^{3-}, \mathrm{Cu}^{2+}, \mathrm{Fe}^{3+}, \mathrm{Mn}^{2+}$, and $\mathrm{Zn}^{2+}$ were determined using Inductively Coupled Plasma (iCAP 6000, Thermo Fisher Scientific Inc., UK). Anions were extracted in tightly closed micro tube with distilled water and finely ground powder at $100^{\circ} \mathrm{C}$ for $1 \mathrm{~h}$ and the supernatant obtained after centrifugation was used to determine anion concentration by ion chromatography (Dionex ICS-900, Nippon Dionex K.K., Osaka, Japan). The contribution of each ion to total osmotic potential at full turgor $\left(\Psi_{\pi}^{100}\right)$ was calculated as described by Ming et al. (2012).

The malondialdehyde (MDA) content was measured using a modified version of the thiobarbituric acid (TBA) procedure (Draper and Hadley, 1990). The fine powder (ground with liquid nitrogen) of young leaf blade was homogenized by an extraction buffer containing $3.3 \mathrm{~m} M$ HEPES ( $\mathrm{pH} 7$ ), $0.25 \%$ TBA, $10 \%$ trichloroacetic acid (TCA), $0.2 \mathrm{M} \mathrm{HCl}, 0.01 \%$ butylated hydroxytoluene, and $1.3 \%$ ethanol. The absorbance of the supernatant acquired after centrifugation was measured at $535 \mathrm{~nm}$ and $600 \mathrm{~nm}$ after incubating at $95^{\circ} \mathrm{C}$, and the extinction coefficient $\left(1.56 \times 10^{5} \mathrm{mM}^{-1} \mathrm{~cm}^{-1}\right)$ was used to calculate the MDA content.

The crude extract for measuring enzyme activity and protein concentration was prepared as described by Koca et al. (2007), with modifications. A frozen sample ( $0.5 \mathrm{~g})$ was extracted with ice-cold $25 \mathrm{~m} M$ potassium phosphate buffer (pH 7.8) containing $0.5 \mathrm{~m} M$ ethylenediaminetetraacetic acid (EDTA), 2\% polyvinylpolypyrrolidone, and $1 \mathrm{~m} M$ ascorbic acid. For CAT activity, it was assayed by measuring the initial rate of $\mathrm{H}_{2} \mathrm{O}_{2}$ disappearance at $240 \mathrm{~nm}$ (Aebi, 1984). For APX activity, the absorbance of ascorbic acid was determined at $290 \mathrm{~nm}$ (Nakano and Asada, 1981). For GPX activity, the absorbance of tetraguaiacol was measured at $470 \mathrm{~nm}$ (Velikova et al., 2000). For GR activity, the absorption of oxidized NADPH was monitored at $340 \mathrm{~nm}$ as described by Foyer and Halliwell (1976). The soluble protein content in the enzyme extract was determined as descripted by Assaha et al. (2015).

\section{Statistical Analysis}

All data were examined by one-way ANOVA using the IBM SPSS statistical package version 21. Test of significance was performed using Duncan's test at the 5\% significance level. The values are means $( \pm \mathrm{SE})$ of six replicates.

\section{Results}

\section{Plant Growth}

The root DW of Swiss chard was $23 \%$ less, and shoot DW was not changed with Alkalinity $+2 \mathrm{~m} M \mathrm{~K}$ treatment compared to those of $2 \mathrm{mMK}$ treatment (Fig. 1). Additionally, the root DW was $43 \%$ less, shoot DW was $30 \%$ less with $0 \mathrm{~m} M \mathrm{~K}$ treatment, and root DW was $45 \%$ less, shoot DW was $33 \%$ less with Alkalinity $+0 \mathrm{~m} M \mathrm{~K}$ treatments when compared with the root and shoot DW with $2 \mathrm{~m} M \mathrm{~K}$ treatment. Therefore, the reductions in plant growth caused by $0 \mathrm{~m} M \mathrm{~K}$ and Alkalinity $+0 \mathrm{~m} M \mathrm{~K}$ treatments were greater than of the plants subjected to Alkalinity+2 $\mathrm{m} M \mathrm{~K}$ treatment. Also, leaf chlorosis phenomenon was observed in plants after treatment of Alkalinity $+0 \mathrm{~m} M \mathrm{~K}$.

\section{Water Relations}

The results indicated that the RWC was $6 \%, 8 \%$, and $16 \%$ less, respectively, with $0 \mathrm{~m} M \mathrm{~K}$, Alkalinity $+2 \mathrm{~m} M \mathrm{~K}$, and Alkalinity $+0 \mathrm{~m} M \mathrm{~K}$ treatments when compared to $2 \mathrm{~m} M \mathrm{~K}$ treatment (Fig. 2). In addition, the $\Psi_{\pi}^{100}$ was $15 \%$ less with Alkalinity $+2 \mathrm{~m} M \mathrm{~K}$ treatment, $18 \%$ more with $0 \mathrm{~m} M \mathrm{~K}$ treatment, and $13 \%$ more with Alkalinity $+0 \mathrm{~m} M \mathrm{~K}$ treatments compared to $2 \mathrm{~m} M \mathrm{~K}$ treatment.

\section{Cation and Anion Contents}

Plants subjected to $0 \mathrm{~m} M \mathrm{~K}$ and Alkalinity $+0 \mathrm{~m} M \mathrm{~K}$ treatments, $\mathrm{Ca}^{2+}$ content in young leaves were higher than in plants subjected to $2 \mathrm{~m} M \mathrm{~K}$ and Alkalinity $+2 \mathrm{~m} M \mathrm{~K}$ treatments (Table 1). $\mathrm{Ca}^{2+}$ content was $75 \%$ more with 0 $\mathrm{m} M \mathrm{~K}, 48 \%$ more with Alkalinity $+0 \mathrm{~m} M \mathrm{~K}$; while $19 \%$ less with Alkalinity $+2 \mathrm{~m} M \mathrm{~K}$ treatments when compared to 2 $\mathrm{m} M \mathrm{~K}$ treatment. $\mathrm{Mg}^{2+}$ contents in leaf tissues of Swiss chard was $90 \%, 107 \%$, and $52 \%$ more with $0 \mathrm{~m} M \mathrm{~K}$, Alkalinity $+0 \mathrm{~m} M \mathrm{~K}$, and Alkalinity $+2 \mathrm{~m} M \mathrm{~K}$ treatments, respectively compared to $2 \mathrm{~m} M \mathrm{~K}$ treatment. The presence of a mixture of $\mathrm{NaHCO}_{3}$ and $\mathrm{Na}_{2} \mathrm{CO}_{3}$ in the culture medium resulted with 32- and 34-fold greater leaf $\mathrm{Na}^{+}$content in Alkalinity $+0 \mathrm{~m} M \mathrm{~K}$ and Alkalinity $+2 \mathrm{~m} M \mathrm{~K}$ treatments, respectively. It is 4-fold greater in $0 \mathrm{~m} M \mathrm{~K}$ treatment compared to $2 \mathrm{~m} M \mathrm{~K}$ treatment. Potassium content was $82 \%, 57 \%$, and $55 \%$ lower in young leaves of Swiss chard with Alkalinity $+0 \mathrm{~m} M \mathrm{~K}$, Alkalinity $+2 \mathrm{~m} M \mathrm{~K}$, and $0 \mathrm{~m} M$ $\mathrm{K}$ treatments, respectively compared to $2 \mathrm{~m} M \mathrm{~K}$ treatment. Consequently, the lowest $\mathrm{Na}^{+} / \mathrm{K}^{+}$ratio was observed with $2 \mathrm{~m} M \mathrm{~K}$ treatment. For example, the $\mathrm{Na}^{+} / \mathrm{K}^{+}$ratio was 7 -fold, 182 -fold, and 79-fold higher in young leaves of Swiss chard with $0 \mathrm{~m} M \mathrm{~K}$, Alkalinity +0 $\mathrm{m} M \mathrm{~K}$, and Alkalinity $+2 \mathrm{~m} M \mathrm{~K}$ treatments, respectively compared to $2 \mathrm{~m} M \mathrm{~K}$ treatment.

On the other hand, it was observed that $\mathrm{Cl}^{-}$content was significant lower with all treatments compared to $2 \mathrm{mM}$ $\mathrm{K}$ treatments. It was $92 \%, 96 \%$ and $84 \%$ lower after treatments with Alkalinity $+0 \mathrm{~m} M \mathrm{~K}$, Alkalinity $+2 \mathrm{~m} M \mathrm{~K}$, and $0 \mathrm{~m} M \mathrm{~K}$, respectively, compared to $2 \mathrm{~m} M \mathrm{~K}$ treatment. The $\mathrm{NO}_{3}{ }^{-}$content was 7-fold, 4-fold and 1.6-fold greater in Alkalinity $+0 \mathrm{~m} M \mathrm{~K}$, Alkalinity $+2 \mathrm{~m} M \mathrm{~K}$, and $0 \mathrm{~m} M \mathrm{~K}$ treatments, respectively compared to $2 \mathrm{~m} M \mathrm{~K}$ treatment. 
Table 1: Changes in the contents of cations and anions $\left(\mathrm{mg} \mathrm{g}^{-1} \mathrm{DW}\right)$, and $\mathrm{Na}^{+} / \mathrm{K}^{+}$ratio in young leaves in response to alkaline and $\mathrm{K}^{+}$treatments

\begin{tabular}{lllll}
\hline Measurements & \multicolumn{3}{c}{ Treatments } \\
\cline { 2 - 5 } & $0 \mathrm{~m} M \mathrm{~K}$ & $2 \mathrm{~m} M \mathrm{~K}$ & Alkalinity $+0 \mathrm{~m} M \mathrm{~K}$ & Alkalinity $+2 \mathrm{~m} M \mathrm{~K}$ \\
\hline $\mathrm{Cation}_{\mathrm{Ca}^{2+}}$ & $4.03 \pm 0.22^{\mathrm{a}}$ & $2.30 \pm 0.28^{\mathrm{bc}}$ & $3.4 \pm 0.52^{\mathrm{ab}}$ & $1.86 \pm 0.21^{\mathrm{c}}$ \\
$\mathrm{Mg}^{2+}$ & $8.80 \pm 0.66^{\mathrm{a}}$ & $4.62 \pm 0.46^{\mathrm{b}}$ & $9.59 \pm 1.31^{\mathrm{a}}$ & $7.00 \pm 0.74^{\mathrm{ab}}$ \\
$\mathrm{Na}^{+}$ & $8.35 \pm 0.84^{\mathrm{b}}$ & $2.25 \pm 0.22^{\mathrm{c}}$ & $73.58 \pm 3.30^{\mathrm{a}}$ & $79.18 \pm 5.21^{\mathrm{a}}$ \\
$\mathrm{K}^{+}$ & $34.78 \pm 0.93^{\mathrm{b}}$ & $78.06 \pm 4.43^{\mathrm{a}}$ & $14.15 \pm 1.36^{\mathrm{c}}$ & $33.45 \pm 1.79^{\mathrm{b}}$ \\
$\mathrm{Na}^{+} / \mathrm{K}^{+}$ & $0.24 \pm 0.03^{\mathrm{c}}$ & $0.03 \pm 0.00^{\mathrm{d}}$ & $5.50 \pm 0.66^{\mathrm{a}}$ & $2.39 \pm 0.19^{\mathrm{b}}$ \\
$\mathrm{Anion}$ & & & & \\
$\mathrm{Cl}^{-}$ & $1.80 \pm 0.15^{\mathrm{c}}$ & $23.57 \pm 2.09^{\mathrm{a}}$ & $0.84 \pm 0.09^{\mathrm{d}}$ & $3.74 \pm 0.41^{\mathrm{b}}$ \\
$\mathrm{NO}_{3}{ }^{3-}$ & $3.37 \pm 0.90^{\mathrm{b}}$ & $2.09 \pm 0.86^{\mathrm{bc}}$ & $15.32 \pm 4.49^{\mathrm{a}}$ & $8.29 \pm 3.62^{\mathrm{ab}}$ \\
$\mathrm{PO}_{4}{ }^{3-}$ & $23.68 \pm 1.73^{\mathrm{a}}$ & $27.19 \pm 1.57^{\mathrm{a}}$ & $5.79 \pm 0.59^{\mathrm{b}}$ & $3.46 \pm 0.34^{\mathrm{b}}$ \\
\hline
\end{tabular}

Swiss chard (Beta vulgaris L. subsp. cicla) grown either in a nutrient solution without $(0 \mathrm{~m} M \mathrm{~K})$ or with $(2 \mathrm{~m} M \mathrm{~K}) \mathrm{K}^{+}$, or in a sodic-alkaline nutrient solution without (alkalinity $+0 \mathrm{~m} M \mathrm{~K}$ ) or with (alkalinity $+2 \mathrm{~m} M \mathrm{~K}) \mathrm{K}^{+}$. The values are means $( \pm \mathrm{SE}$ ) of six replicates. Followed by the same letters are not significantly different at $\mathrm{P} \leq 0.05$

Table 2: Changes in boron $\left(\mathrm{BO}_{3}^{3-}\right)$, copper $\left(\mathrm{Cu}^{2+}\right)$, iron $\left(\mathrm{Fe}^{3+}\right)$, manganese $\left(\mathrm{Mn}^{2+}\right)$, and zinc $\left(\mathrm{Zn}^{2+}\right)$ contents $\left(\mu \mathrm{g} \mathrm{g}{ }^{-1} \mathrm{DW}\right)$ in young leaves in response to alkaline and $\mathrm{K}^{+}$treatments

\begin{tabular}{lllll}
\hline Measurements & \multicolumn{4}{c}{ Treatments } \\
\cline { 2 - 5 } & $0 \mathrm{~m} M \mathrm{~K}$ & $2 \mathrm{~m} M \mathrm{~K}$ & Alkalinity $+0 \mathrm{~m} M \mathrm{~K}$ & Alkalinity $+2 \mathrm{~m} M \mathrm{~K}$ \\
\hline $\mathrm{BO}_{3}{ }^{3-}$ & $27.53 \pm 1.27^{\mathrm{b}}$ & $41.97 \pm 1.87^{\mathrm{a}}$ & $17.40 \pm 2.03^{\mathrm{c}}$ & $27.75 \pm 1.82^{\mathrm{b}}$ \\
$\mathrm{Cu}^{2+}$ & $2.91 \pm 0.53^{\mathrm{ab}}$ & $3.31 \pm 0.39^{\mathrm{a}}$ & $2.68 \pm 0.32^{\mathrm{ab}}$ & $1.59 \pm 0.19^{\mathrm{b}}$ \\
$\mathrm{Fe}^{3+}$ & $169.63 \pm 20.83^{\mathrm{a}}$ & $79.56 \pm 4.57^{\mathrm{b}}$ & $43.24 \pm 2.35^{\mathrm{c}}$ & $52.89 \pm 2.48^{\mathrm{bc}}$ \\
$\mathrm{Mn}^{2+}$ & $139.06 \pm 12.22^{\mathrm{b}}$ & $234.09 \pm 29.11^{\mathrm{a}}$ & $157.79 \pm 14.28^{\mathrm{b}}$ & $181.40 \pm 16.67^{\mathrm{ab}}$ \\
$\mathrm{Zn}^{2+}$ & $13.41 \pm 0.95^{\mathrm{b}}$ & $21.93 \pm 1.34^{\mathrm{a}}$ & $9.23 \pm 0.77^{\mathrm{c}}$ & $10.19 \pm 0.92^{\mathrm{c}}$ \\
\hline
\end{tabular}

Swiss chard (Beta vulgaris L. subsp. cicla) grown either in a nutrient solution without $(0 \mathrm{~m} M \mathrm{~K})$ or with $(2 \mathrm{mM} \mathrm{K}) \mathrm{K}^{+}$, or in a sodic-alkaline nutrient solution without (alkalinity $+0 \mathrm{~m} M \mathrm{~K}$ ) or with (alkalinity $+2 \mathrm{~m} M \mathrm{~K}) \mathrm{K}^{+}$. The values are means $( \pm \mathrm{SE})$ of six replicates. Followed by the same letters are not significantly different at $\mathrm{P} \leq 0.05$

$\mathrm{PO}_{4}{ }^{3-}$ content was unchanged by $0 \mathrm{~m} M \mathrm{~K}$ treatment, and significant lower with Alkalinity $+2 \mathrm{~m} M \mathrm{~K}(79 \%)$ and Alkalinity+0 $\mathrm{m} M \mathrm{~K}(87 \%)$ treatments compared to $2 \mathrm{~m} M \mathrm{~K}$ treatment.

\section{Micronutrient Contents}

Borate $\left(\mathrm{BO}_{3}{ }^{3-}\right)$ contents was $34 \%, 59 \%$ and $34 \%$ less in treatments of $0 \mathrm{~m} M \mathrm{~K}$, Alkalinity $+0 \mathrm{~m} M \mathrm{~K}$ and Alkalinity +2 $\mathrm{m} M \mathrm{~K}$, compared to $2 \mathrm{~m} M \mathrm{~K}$ treatment (Table 3). Copper $\left(\mathrm{Cu}^{2+}\right)$ content was $12 \%, 19 \%$, and $52 \%$ less in $0 \mathrm{mM} \mathrm{K}$, Alkalinity $+0 \mathrm{~m} M \mathrm{~K}$, and Alkalinity $+2 \mathrm{~m} M \mathrm{~K}$ treatments, respectively, compared to $2 \mathrm{mM} \mathrm{K}$ treatment. Iron $\left(\mathrm{Fe}^{3+}\right)$ content was 2-fold greater with $0 \mathrm{mM} \mathrm{K}$ treatment, while 0.46 - and 0.34 -fold lower with Alkalinity $+0 \mathrm{mM} \mathrm{K}$, and Alkalinity $+2 \mathrm{~m} M \mathrm{~K}$ treatments, respectively, compared to 2 $\mathrm{m} M \mathrm{~K}$ treatment. Manganese $\left(\mathrm{Mn}^{2+}\right)$ content was 0.41 , 0.33 -, and 0.23 -folds lower with $0 \mathrm{~m} M \mathrm{~K}$, Alkalinity $+0 \mathrm{~m} M$ $\mathrm{K}$, and Alkalinity $+2 \mathrm{mM} \mathrm{K}$ treatments, respectively compared to $2 \mathrm{~m} M \mathrm{~K}$ treatment. Zinc $\left(\mathrm{Zn}^{2+}\right)$ content was $0.39-, 0.58$-, and 0.54 -fold lower with $0 \mathrm{~m} M \mathrm{~K}$, Alkalinity +0 $\mathrm{m} M \mathrm{~K}$, and Alkalinity $+2 \mathrm{~m} M \mathrm{~K}$ treatments, respectively compared to $2 \mathrm{~m} M \mathrm{~K}$ treatment.

\section{Contribution of Each Ion to Osmotic Potentials of Ions at Full Turgor}

The percentage contribution of each ion at $\Psi_{\pi}^{100}$ from highest to lowest was as follows: $\mathrm{K}^{+}, \mathrm{Na}^{+}, \mathrm{Mg}^{2+}, \mathrm{PO}_{4}{ }^{3-}$, $\mathrm{Ca}^{2+}, \mathrm{NO}_{3}{ }^{-}, \mathrm{Cl}^{-}$and micronutrients for $0 \mathrm{~m} M \mathrm{~K}$ plants (Table 3). The order for $2 \mathrm{mM}$ plants was $\mathrm{K}^{+}, \mathrm{Cl}^{-}, \mathrm{PO}_{4}^{3-}, \mathrm{Mg}^{2+}, \mathrm{Na}^{+}$, $\mathrm{Ca}^{2+}, \mathrm{NO}_{3}^{-}$, and micronutrients. However, the percentage contribution of each ion at $\Psi_{\pi}^{100}$ from highest to lowest changed as follows: $\mathrm{Na}^{+}, \mathrm{Mg}^{2+}, \mathrm{K}^{+}, \mathrm{NO}_{3}^{-}, \mathrm{Ca}^{2+}, \mathrm{PO}_{4}{ }^{3-}, \mathrm{Cl}^{-}$, and micronutrients for Alkalinity $+0 \mathrm{~m} M \mathrm{~K}$ plants, and $\mathrm{Na}^{+}$, $\mathrm{K}^{+}, \mathrm{Mg}^{2+}, \mathrm{NO}_{3}^{-}, \mathrm{Cl}^{-}, \mathrm{Ca}^{2+}, \mathrm{PO}_{4}^{3-}$, and micronutrients for Alkalinity $+2 \mathrm{~m} M \mathrm{~K}$ plants.

\section{Malondialdehyde Content and Antioxidant Enzyme Activities}

The lowest value of MDA content was observed in leaf tissues of $2 \mathrm{~m} M \mathrm{~K}$ treatment and it was $8 \%$ more in Alkalinity $+2 \mathrm{mM} \mathrm{K}$ treatment, $26 \%$ more in Alkalinity +0 $\mathrm{m} M \mathrm{~K}$ treatment, and $88 \%$ more in $0 \mathrm{~m} M \mathrm{~K}$ treatment compared to $2 \mathrm{~m} M \mathrm{~K}$ treatment (Fig. 3).

For the antioxidants enzymes, the CAT, APX, GPX, and GR activities decreased in treatments without $\mathrm{K}$ (Table 4). For example, CAT, APX, GPX and GR activities were $77 \%, 51 \%, 45 \%$ and $41 \%$ lower, respectively in $0 \mathrm{mM} \mathrm{K}$ treatment compared to $2 \mathrm{mM} \mathrm{K}$ treatment and were also $82 \%, 58 \%, 57 \%$, and $87 \%$ less, respectively in Alkalinity +0 $\mathrm{m} M \mathrm{~K}$ treatment compared to $2 \mathrm{~m} M \mathrm{~K}$ treatment. With Alkalinity $+2 \mathrm{~m} M \mathrm{~K}$ treatment, CAT, APX, and GR activities were $69 \%, 33 \%$, and $75 \%$ lower, respectively, whereas GPX activity was $7 \%$ higher compared to the $2 \mathrm{~m} M \mathrm{~K}$ treatment. 
Table 3: Percentage contribution of each ion to total osmotic potential at full turgor in young leaves in response to alkaline and $\mathrm{K}^{+}$treatments

\begin{tabular}{lllll}
\hline Measurements & \multicolumn{4}{c}{ Treatments } \\
\cline { 2 - 5 } & $0 \mathrm{~m} M \mathrm{~K}$ & $2 \mathrm{~m} M \mathrm{~K}$ & Alkalinity $+0 \mathrm{~m} M \mathrm{~K}$ & $0.94 \pm 0.05^{\mathrm{c}}$ \\
$\mathrm{Ca}^{2+}(\%)$ & $4.84 \pm 0.22^{\mathrm{a}}$ & $1.72 \pm 0.20^{\mathrm{bc}}$ & $1.94 \pm 0.39^{\mathrm{b}}$ & $5.86 \pm 0.67^{\mathrm{c}}$ \\
$\mathrm{Mg}^{2+}(\%)$ & $17.42 \pm 1.49^{\mathrm{a}}$ & $5.70 \pm 0.52^{\mathrm{c}}$ & $9.00 \pm 1.37^{\mathrm{b}}$ & $70.05 \pm 1.66^{\mathrm{a}}$ \\
$\mathrm{Na}^{+}(\%)$ & $17.48 \pm 1.78^{\mathrm{b}}$ & $2.93 \pm 0.08^{\mathrm{c}}$ & $73.09 \pm 1.45^{\mathrm{a}}$ & $17.40 \pm 0.89^{\mathrm{c}}$ \\
$\mathrm{K}^{+}(\%)$ & $42.81 \pm 2.54^{\mathrm{b}}$ & $59.85 \pm 2.09^{\mathrm{a}}$ & $8.27 \pm 1.13^{\mathrm{d}}$ & $2.15 \pm 0.37^{\mathrm{b}}$ \\
$\mathrm{Cl}^{-}(\%)$ & $2.45 \pm 0.31^{\mathrm{b}}$ & $19.92 \pm 1.59^{\mathrm{a}}$ & $0.54 \pm 0.08^{\mathrm{c}}$ & $2.72 \pm 1.52^{\mathrm{ab}}$ \\
$\mathrm{NO}_{3}^{-}(\%)$ & $2.61 \pm 0.50^{\mathrm{b}}$ & $1.01 \pm 0.63^{\mathrm{bc}}$ & $5.64 \pm 2.02^{\mathrm{a}}$ & $0.74 \pm 0.12^{\mathrm{c}}$ \\
$\mathrm{PO}_{4}{ }^{3-}(\%)$ & $12.00 \pm 0.84^{\mathrm{a}}$ & $8.58 \pm 1.26^{\mathrm{b}}$ & $1.39 \pm 0.20^{\mathrm{c}}$ & $0.14 \pm 0.01^{\mathrm{c}}$ \\
$\left.\mathrm{Micronutrients}^{\mathrm{c}} \%\right)$ & $0.40 \pm 0.03^{\mathrm{a}}$ & $0.30 \pm 0.01^{\mathrm{b}}$ & $0.12 \pm 0.00^{\mathrm{c}}$ & \\
\hline
\end{tabular}

Swiss chard (Beta vulgaris L. subsp. cicla) grown either in a nutrient solution without $(0 \mathrm{~m} M \mathrm{~K})$ or with $(2 \mathrm{~m} M \mathrm{~K}) \mathrm{K}^{+}$, or in a sodic-alkaline nutrient solution without (alkalinity $+0 \mathrm{~m} M \mathrm{~K}$ ) or with (alkalinity $+2 \mathrm{~m} M \mathrm{~K}$ ) $\mathrm{K}^{+}$. The values are means $( \pm \mathrm{SE}$ ) of six replicates. Followed by the same letters are not significantly different at $\mathrm{P} \leq 0.05$

Table 4: Changes in activity of catalase (CAT), ascorbate peroxidase (APX), guaiacol peroxidase (GPX), and glutathione reductase $(\mathrm{GR})$ in young leaves in response to alkaline and $\mathrm{K}^{+}$treatments

\begin{tabular}{|c|c|c|c|c|}
\hline \multirow[t]{2}{*}{ Measurements } & \multicolumn{4}{|c|}{ Treatments } \\
\hline & $0 \mathrm{~m} M \mathrm{~K}$ & $2 \mathrm{~m} M \mathrm{~K}$ & Alkalinity $+0 \mathrm{~m} M \mathrm{~K}$ & Alkalinity $+2 \mathrm{~m} M \mathrm{~K}$ \\
\hline CAT (m $M \min ^{-1} \mathrm{mg}^{-1}$ protein) & $54.86 \pm 8.09^{b}$ & $130.62 \pm 14.56^{\mathrm{a}}$ & $23.30 \pm 4.49^{\mathrm{c}}$ & $39.86 \pm 6.95^{\mathrm{bc}}$ \\
\hline $\mathrm{APX}\left(\mu \mathrm{mol} \mathrm{min}^{-1} \mathrm{mg}^{-1}\right.$ protein $)$ & $1096.10 \pm 181.63^{\mathrm{b}}$ & $2246.28 \pm 152.61^{\mathrm{a}}$ & $948.37 \pm 127.47^{b}$ & $1505.08 \pm 278.96^{\mathrm{b}}$ \\
\hline GR $\left(\mu \mathrm{mol} \min ^{-1} \mathrm{mg}^{-1}\right.$ protein $)$ & $494.55 \pm 122.57^{b}$ & $843.21 \pm 148.09^{\mathrm{a}}$ & $113.25 \pm 6.92^{\mathrm{c}}$ & $214.07 \pm 35.90^{\mathrm{bc}}$ \\
\hline
\end{tabular}

Swiss chard (Beta vulgaris L. subsp. cicla) grown either in a nutrient solution without $(0 \mathrm{~m} M \mathrm{~K})$ or with $(2 \mathrm{~m} M \mathrm{~K}) \mathrm{K}^{+}$, or in a sodic-alkaline nutrient solution without (alkalinity $+0 \mathrm{~m} M \mathrm{~K})$ or with (alkalinity $+2 \mathrm{~m} M \mathrm{~K}) \mathrm{K}^{+}$. The values are means $( \pm \mathrm{SE})$ of six replicates. Followed by the same letters are not significantly different at $\mathrm{P} \leq 0.05$

These results suggested that, reduction in enzymatic antioxidant capacity in Swiss chard seedlings caused by Alkalinity $+0 \mathrm{~m} M$ treatment was higher than by $0 \mathrm{~m} M \mathrm{~K}$ and Alkalinity $+2 \mathrm{~m} M \mathrm{~K}$ treatments.

\section{Discussion}

The effect of potassium on growth and antioxidant enzymes of Beta vulgaris L. in sodic-alkaline conditions seems to be an important study to investigate the role of $\mathrm{K}^{+}$as a physiological parameter in plant cell. High $\mathrm{pH}$ and excessive $\mathrm{Na}^{+}$in sodic-alkaline soil medium result in serious $\mathrm{K}^{+}$deprivation in living plant cells (Liu et al., 2013). Several studies have reported that a combination of salinity and $\mathrm{K}^{+}$starvation had a greater effect on the growth and productivity of barley and maize (Degl'Innocenti et al., 2009; Hafsi et al., 2010; Gong et al., 2011; Qu et al., 2012). This study showed that the lowest biomass production and chlorosis with Alkalinity $+0 \mathrm{~m} M \mathrm{~K}$ treatment, which indicates that the absence of $\mathrm{K}^{+}$partially intensified the effect of alkalinity on reducing the growth of Swiss chard. As well, the higher biomass production with Alkalinity +2 $\mathrm{m} M \mathrm{~K}$ treatment than with Alkalinity $+0 \mathrm{~m} M \mathrm{~K}$ suggest that pre-treated-plants with $\mathrm{K}^{+}$could resist the detrimental effects of sodic-alkaline conditions. Therefore, $\mathrm{K}^{+}$plays a crucial role in $\mathrm{NaHCO}_{3}$ - and $\mathrm{Na}_{2} \mathrm{CO}_{3}$-treated Swiss chard. At the same time, excessive $\mathrm{CO}_{3}{ }^{2-}$ has its own toxic effect on plant growth because of adverse effects on protein synthesis, respiration, and the absorption of nutrients (Wu and Xing, 2012). High contents of $\mathrm{HCO}_{3}{ }^{-}$ strongly affect the availability of several micronutrients, especially $\mathrm{Fe}$, and it is often considered to be the primary factor inducing Fe chlorosis in leaves (Colla et al., 2010). Also, this study, with Alkalinity $+0 \mathrm{~m} M \mathrm{~K}$ treatment, the combined stress caused by $\mathrm{Na}^{+}$toxicity, $\mathrm{CO}_{3}{ }^{2-}$ and $\mathrm{HCO}_{3}{ }^{-}$toxicities, high $\mathrm{pH}$, and absence of $\mathrm{K}^{+}$, induced the greatest adverse effects on plant growth when compared with other treatments.

Water deficit is the rapid and main consequence that plants experience when exposed to external excessive $\mathrm{Na}^{+}$, and plants can adapt to water deficit by accumulating osmolytes to maintain leaf turgor and physiological activities at relatively low leaf water potential (Ming et al., 2012). From the results here, young leaves of Swiss chard were exposed to water stress in all treatments when compared with $2 \mathrm{~m} M \mathrm{~K}$ treatment and with Alkalinity+0 $\mathrm{m} M \mathrm{~K}$ treatment water stress conditions were greater. Furthermore, osmotic adjustment was not achieved in young leaves of Swiss chard with Alkalinity $+0 \mathrm{~m} M \mathrm{~K}$ treatment, indicating that the harmful effects caused by Alkalinity +0 $\mathrm{m} M \mathrm{~K}$ treatment were more serious than by Alkalinity +2 $\mathrm{m} M \mathrm{~K}$ treatment. Hence, the greater reduction in RWC, increase in $\mathrm{Na}^{+} / \mathrm{K}^{+}$ratio, and lack of osmotic adjustment with Alkalinity $+0 \mathrm{~m} M \mathrm{~K}$ treatment provides strong evidence that absence of $\mathrm{K}^{+}$somewhat intensified the effect of sodicalkalinity on reducing growth of Swiss chard.

The depletion of $\mathrm{K}^{+}$in the cytoplasm was crucial for triggering programmed cell death (Shabala, 2009). Following $\mathrm{K}^{+}$deprivation together with sodic-alkaline treatment, $\mathrm{K}^{+}$deficiency in living cells of Swiss chard was significantly expedited owing to excessive $\mathrm{Na}^{+}$ accumulation, high $\mathrm{pH}$, and reduction in cytoplasmic $\mathrm{K}^{+}$. 


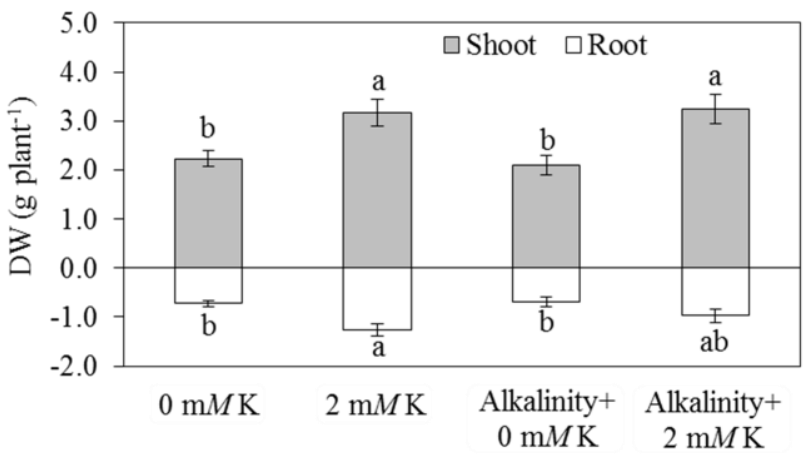

Fig. 1: Changes in shoot dry weight (DW) and root DW in Swiss chard (Beta vulgaris L. subsp. cicla) in response to alkaline and $\mathrm{K}^{+}$treatments. Seedlings were grown either in a nutrient solution or in a sodic-alkaline nutrient solution. The values are means $( \pm$ SE) of six replicates. Followed by the same letters are not significantly different at $\mathrm{P} \leq 0.05$
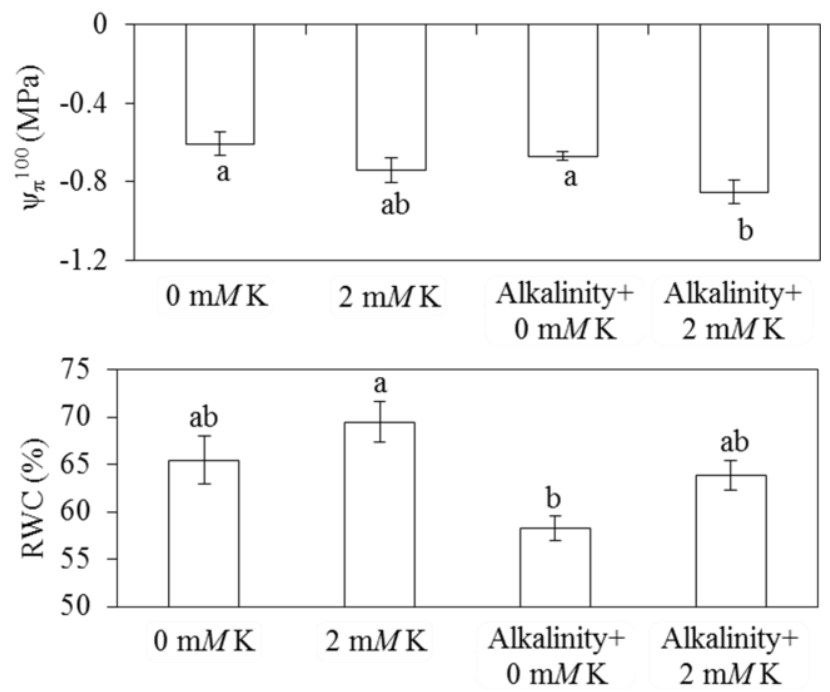

Fig. 2: Changes in relative water content (RWC) and osmotic potential at full turgor $\left(\Psi_{\pi}^{100}\right)$ in young leaves in response to alkaline and $\mathrm{K}^{+}$treatments. Swiss chard (Beta vulgaris L. subsp. cicla) seedlings were grown either in a nutrient solution or in a sodic-alkaline nutrient solution. The values are means $( \pm$ SE) of six replicates. Followed by the same letters are not significantly different at $\mathrm{P} \leq 0.05$

Plant cells of Swiss chard may have sensed the low content of $\mathrm{K}^{+}$and initiated a series of severe physiological reactions, such as water deficit, ionic imbalance, and oxidative damage, and then seriously limited plant growth in Alkalinity $+0 \mathrm{~m} M \mathrm{~K}$ treatment. In the other hand, with Alkalinity $+2 \mathrm{~m} M \mathrm{~K}$ treatment, $\mathrm{K}^{+}$content in living cells of Swiss chard just decreased in the sodic-alkaline treatment period, and maintained at a higher level than that of Alkalinity $+0 \mathrm{~m} M \mathrm{~K}$ treatment. Additionally, in some species of Chenopodiaceae, such as sugar beet and red beet, $\mathrm{Na}^{+}$can substitute for $\mathrm{K}^{+}$localized in vacuoles for osmotic function

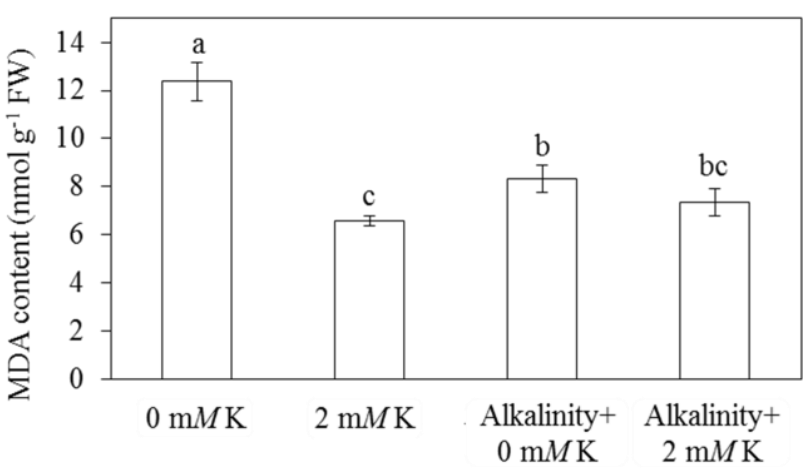

Fig. 3: Changes in malondialdehyde (MDA) content in young leaves in response to alkaline and $\mathrm{K}^{+}$treatments. Swiss chard (Beta vulgaris L. ssp. cicla) seedlings were grown either in a nutrient solution or in a sodic-alkaline nutrient solution. The values are means $( \pm \mathrm{SE})$ of six replicates. Followed by the same letters are not significantly different at $\mathrm{P} \leq 0.05$

to a high degree (Subbarao et al., 2000; Wakeel et al., 2010). For further clarification in this study, in the Alkalinity $+2 \mathrm{~m} M \mathrm{~K}$ treatment, $\mathrm{Na}^{+} / \mathrm{K}^{+}$ratio in young leaves of Swiss chard was increased significantly, however, shoot dry weight was not significantly affected, indicating that $\mathrm{K}^{+}$ ions in vacuoles might be substituted by $\mathrm{Na}^{+}$ions for maintenance of osmotic adjustment. Furthermore, $\mathrm{K}^{+}$ content in living cells were maintained at a higher level, and $\mathrm{Na}^{+}$toxic effect in the cytoplasm was somewhat avoided. In terms of $\mathrm{Na}^{+}$influx and $\mathrm{K}^{+}$efflux from vacuoles, some studies reported that over-expression of tonoplast sodium/proton exchangers (NHXs) improved salt tolerance in Beta vulgaris (Blumwald and Poole, 1987; Xia et al., 2002; Adler et al., 2010), and tonoplast-located $\mathrm{K}^{+}$channels or transporters facilitating $\mathrm{K}^{+}$release from vacuoles into the cytoplasm (Wang and Wu, 2010; Chérel et al., 2014). The ability of Swiss chard to control the cytoplasmic $\mathrm{K}^{+}$ concentration in Alkalinity $+2 \mathrm{~m} M \mathrm{~K}$ and Alkalinity $+0 \mathrm{~m} M$ $\mathrm{K}$ conditions could possibly have been regulated by the over-expression of NHXs or tonoplast-located $\mathrm{K}^{+}$ channels and transporters, however, these phenomena need to be further investigated. Furthermore, $\mathrm{Na}^{+}$was taken up by high-affinity $\mathrm{K}^{+}$transporters (HKTs) from the soil solution to reduce $\mathrm{K}^{+}$requirements (Rodríguez-Navarro and Rubio, 2006). Therefore, the higher value of $\mathrm{Na}^{+}$ content in $0 \mathrm{~m} M \mathrm{~K}$ treatment than in $2 \mathrm{~m} M \mathrm{~K}$ treatment indicates that $\mathrm{Na}^{+}$influx component mediated by the HKT transporter into roots to maintain growth in Swiss chard in 0 $\mathrm{m} M \mathrm{~K}$ treatment.

Elevated cytoplasmic $\mathrm{Ca}^{2+}$ can stimulate NADPH oxidase-mediated production of ROS, and increased ROS levels in turn activate $\mathrm{Ca}^{2+}$-permeable ion channels leading to further $\mathrm{Ca}^{2+}$ influx under $\mathrm{K}^{+}$deprival condition (Wang and $\mathrm{Wu}, 2010)$. Therefore, the higher $\mathrm{Ca}^{2+}$ content in Swiss chard in $0 \mathrm{~m} M \mathrm{~K}$ and Alkalinity $+0 \mathrm{~m} M \mathrm{~K}$ treatments may 
have been caused by the hyperpolarization of cell membranes. This phenomenon was consistent with the significant increase in MDA content in $0 \mathrm{~m} M \mathrm{~K}$ and Alkalinity $+0 \mathrm{~m} M \mathrm{~K}$ treatments in Swiss chard. Also, $\mathrm{Mg}^{2+}$ and $\mathrm{Ca}^{2+}$ in most tissues tends to be sequestered in vacuoles, where they contribute to turgor generation (Maathuis, 2009). The increased $\mathrm{Ca}^{2+}$ content together with $\mathrm{Mg}^{2+}$ was observed in $0 \mathrm{~m} M \mathrm{~K}$ and Alkalinity $+0 \mathrm{~m} M \mathrm{~K}$ treatments to compensate the reduction in osmolarity induced by $\mathrm{K}^{+}$ deficiency in young leaves of Swiss chard. Wakeel et al. (2009) reported that $\mathrm{Ca}^{2+}$ uptake and translocation through xylem sap was inhibited in $\mathrm{Na}^{+}$-treated sugar beet (Beta vulgaris L.). Hence, value of $\mathrm{Ca}^{2+}$ content in Alkalinity +0 $\mathrm{m} M \mathrm{~K}$ treatment was lower than in $0 \mathrm{~m} M \mathrm{~K}$ treatment, and value of $\mathrm{Ca}^{2+}$ content in Alkalinity+2 $\mathrm{m} M \mathrm{~K}$ treatment was lower than in $2 \mathrm{~m} M \mathrm{~K}$ treatment.

Although higher concentrations of $\mathrm{Cl}^{-}$is toxic to plants, it is considered as an essential nutrient that regulates enzyme activities in the cytoplasm, acts as a counter anion to stabilize membrane potential, and is involved in turgor and $\mathrm{pH}$ regulation (Teakle and Tyerman, 2010). Therefore, the reduction in $\mathrm{Cl}^{-}$in $0 \mathrm{~m} M \mathrm{~K}$, Alkalinity+ $0 \mathrm{~m} M \mathrm{~K}$, and Alkalinity $+2 \mathrm{~m} M \mathrm{~K}$ treatments clearly contributed an adverse effect to the natural physiological metabolism processes of Swiss chard plants in these treatments. From a $\mathrm{Cl}^{-}$perspective, the efflux of $\mathrm{Cl}^{-}$could be balanced by the uptake of another anion. $\mathrm{NO}_{3}{ }^{-} / \mathrm{Cl}^{-}$interactions are analogous to $\mathrm{K}^{+} / \mathrm{Na}^{+}$interactions and many anion channels are more selective for $\mathrm{NO}_{3}{ }^{-}$than $\mathrm{Cl}^{-}$(Teakle and Tyerman, 2010). In Alkalinity $+2 \mathrm{~m} M \mathrm{~K}$ and Alkalinity $+0 \mathrm{~m} M \mathrm{~K}$ treatments, the obvious inductions of $\mathrm{NO}_{3}{ }^{-}$would likely offset the scarcity of anions caused by sharp reductions in $\mathrm{Cl}^{-}$. Whereas, in the $0 \mathrm{~m} M \mathrm{~K}$ treatment, the scarcity of anions caused by sharp reductions in $\mathrm{Cl}^{-}$was offset by $\mathrm{PO}_{4}{ }^{3-}$. In addition, $\mathrm{NO}_{3}{ }^{-}$is the predominant form of inorganic nitrogen in high-pH soils, and sodium enhances root-to-leaf nitrate translocation in Swiss chard (Maathuis, 2009; Emi et al., 2015). The obvious inductions of $\mathrm{NO}_{3}^{-}$in Alkalinity+2 $\mathrm{m} M \mathrm{~K}$ and Alkalinity $+0 \mathrm{~m} M \mathrm{~K}$ treatments may also have affected due to high $\mathrm{pH}$ and excessive $\mathrm{Na}^{+}$, caused by $\mathrm{NaHCO}_{3}$ and $\mathrm{Na}_{2} \mathrm{CO}_{3}$. The $\mathrm{PO}_{4}{ }^{3-}$ contents decreased sharply, because of the precipitation of $\mathrm{PO}_{4}{ }^{3-}$ at higher $\mathrm{pH}$ in the environment surrounding the roots under Alkalinity $+2 \mathrm{~m} M \mathrm{~K}$ and Alkalinity $+0 \mathrm{~m} M \mathrm{~K}$ treatments.

Micronutrients are essential for plant growth but are required in much smaller amounts than macronutrients (Hänsch and Mendel, 2009). They involve in all metabolic and cellular functions, and deficiency in any one of these trace elements reduces plant growth and crop yield (Hänsch and Mendel, 2009; White and Brown, 2010). However, $\mathrm{Cu}^{2+}, \mathrm{Fe}^{3+}, \mathrm{Mn}^{2+}$, and $\mathrm{Zn}^{2+}$ contents in young leaves of Swiss chard decreased, because of the limited phytoavailability of these elements at high $\mathrm{pH}$ in Alkalinity $+2 \mathrm{~m} M \mathrm{~K}$ and Alkalinity +0 $\mathrm{m} M$ treatments. Furthermore, $\mathrm{BO}_{3}{ }^{3-}$ can promote the structural integrity of bio-membranes (Brown et al., 2002;
Hänsch and Mendel, 2009). The significant decrease of $\mathrm{BO}_{3}{ }^{3-}$ content in Alkalinity $+2 \mathrm{~m} M \mathrm{~K}$ and Alkalinity $+0 \mathrm{~m} M$ $\mathrm{K}$ treatments might contribute to damage to the cell membrane in young leaves of Swiss chard in these treatments.

Osmotic adjustment helps plants to maintain turgor under water stress. Although organic components were the major components that contribute to osmotic adjustment in plants, inorganic components also involved (Kusaka et al., 2005). In this study, $\mathrm{K}^{+}$was the major inorganic component contributing to osmotic adjustment in living cells of Swiss chard in $0 \mathrm{~m} M \mathrm{~K}$ and $2 \mathrm{~m} M \mathrm{~K}$ treatments. In contrast, in Alkalinity $+0 \mathrm{~m} M \mathrm{~K}$ and Alkalinity $+2 \mathrm{~m} M$ treatments, influx of excess $\mathrm{Na}^{+}$causes ionic imbalance in the living cells, and $\mathrm{Na}^{+}$was used to substitute for $\mathrm{K}^{+}$for osmotic adjustment in young leaves of Swiss chard.

Oxidative stress occurs owing to the rapid accumulation of ROS in response to nutrimental starvation and salinity (Zhu, 2001; Shin et al., 2005), and results in the damage of cell membrane. From the results of this study, the greater increase in MDA content by $0 \mathrm{mM} \mathrm{K}$ treatment than that by Alkalinity $+0 \mathrm{~m} M \mathrm{~K}$ and Alkalinity $+2 \mathrm{~m} M \mathrm{~K}$ treatments, suggests that cell membrane damage was severe in $0 \mathrm{~m} M \mathrm{~K}$ treatment than in Alkalinity $+0 \mathrm{~m} M \mathrm{~K}$ and Alkalinity $+2 \mathrm{~m} M \mathrm{~K}$ treatments. This phenomenon is consistent with the results of Pi et al. (2014), who reported that MDA content was significantly lower in the replacement of $\mathrm{K}^{+}$by $\mathrm{Na}^{+}$groups than in $\mathrm{K}^{+}$-deficient groups in sugar beet with either a salt-sensitive genotype or a salt-tolerant one. They suggested that the substitution of $\mathrm{K}^{+}$by $\mathrm{Na}^{+}$in the living cells alleviates damage to the cytomembrane. This phenomenon may prove the hypothesis that $\mathrm{K}^{+}$ions in vacuoles are replaced by excessive cytoplasmic $\mathrm{Na}^{+}$ions for the maintenance of cytoplasmic $\mathrm{K}^{+}$, and then the protection of cytomembrane in Swiss chard. Among all the treatments, the MDA content was the highest in $0 \mathrm{~m} M \mathrm{~K}$ treatment. Previous reports already suggested that the iron-catalyzed Haber-Weiss reaction is considered as the major mechanism for generating $\mathrm{OH}^{-}$in biological systems, which together with $\mathrm{H}_{2} \mathrm{O}_{2}$ induces $\mathrm{K}^{+}$ efflux and $\mathrm{Ca}^{2+}$ influx from the plasma membrane (Kehrer, 2000; Demidchik et al., 2003; Demidchik et al., 2007; Zepeda-Jazo et al., 2011). Therefore, higher $\mathrm{Fe}^{3+}$ and $\mathrm{Ca}^{2+}$ contents, less $\mathrm{K}^{+}$content, and lower enzyme activities (CAT, APX, GPX and GR) in $0 \mathrm{~m} M \mathrm{~K}$ treatment compared to 2 $\mathrm{m} M \mathrm{~K}$ treatment, provided a strong evidence for the overproduction of $\mathrm{OH}^{\cdot}$ and $\mathrm{H}_{2} \mathrm{O}_{2}$ in Swiss chard in $0 \mathrm{mMK}$ treatment.

APX, followed by CAT, are the key enzymes in detoxifying $\mathrm{H}_{2} \mathrm{O}_{2}$. However, the results here indicated the activities of APX, CAT and GR were decreased in $0 \mathrm{~m} M \mathrm{~K}$, Alkalinity $+0 \mathrm{~m} M \mathrm{~K}$, and Alkalinity $+2 \mathrm{~m} M \mathrm{~K}$ treatments compared to those of $2 \mathrm{~m} M \mathrm{~K}$ treatment. The reductions in their activities may be caused by the clear reductions in $\mathrm{K}^{+}$, $\mathrm{Cl}^{-}, \mathrm{Fe}^{3+}$, and $\mathrm{Mn}^{2+}$ contents in living cells. This is because $\mathrm{K}^{+}$is involved in the activation of enzymes as the most 
abundant cation in the cytoplasm, and other elements are also involved with the oxidative enzymes. Among all the treatments, the integrality of cell membrane was most damaged in leaf tissues in $0 \mathrm{~m} M \mathrm{~K}$ treatment, while the lowest activities of CAT, APX, GPX and GR were observed in leaf tissues in Alkalinity $+0 \mathrm{~m} M \mathrm{~K}$ treatment. It suggested that the significantly increased $\mathrm{Fe}^{3+}$ content may supply sufficient electrons for $\mathrm{OH}^{*}$ formation, which may cause major ROS, inducing cell membrane damage in Swiss chard in $0 \mathrm{~m} M \mathrm{~K}$ treatment. In sugar beet and wild beet, increased GPX was found to protect the plants against oxidative stress during $\mathrm{NaCl}$ stress (Bor et al., 2003). In our study, the reduction in GPX activity coincided with the decrease in shoot DW in $0 \mathrm{~m} M \mathrm{~K}$ and Alkalinity $+0 \mathrm{~m} M \mathrm{~K}$ treatments. Unaltered GPX activity in Alkalinity $+2 \mathrm{~m} M \mathrm{~K}$ treatment coincided with unaltered shoot DW of Swiss chard. Also, GPX protected the plant against oxidative stress in Alkalinity $+2 \mathrm{~m} M \mathrm{~K}$ treatment, while this protective function was lacking in $0 \mathrm{~m} M \mathrm{~K}$ and Alkalinity $+0 \mathrm{~m} M \mathrm{~K}$ treatments. Therefore, GPX in Swiss chard may be involved in scavenging of $\mathrm{H}_{2} \mathrm{O}_{2}$.

In conclusion, $\mathrm{K}^{+}$supplementation effectively alleviated tolerance to sodic-alkaline stress in Swiss chard seedlings, with its ability to increase cell extension in young leaves. Increased concentrations of $\mathrm{K}^{+}, \mathrm{Cl}^{-}, \mathrm{BO}_{3}^{-}, \mathrm{Fe}^{3+}$ and $\mathrm{Mn}^{2+}$, and maintenance of GPX activity also contributed positively. In addition, the favorable changes of $\mathrm{Ca}^{2+}$ influx, $\mathrm{K}^{+}$efflux, tissue water status, and greater enzyme activities (CAT, APX, GPX and GR) also contributed to the increased tolerance to sodic-alkaline stress conditions exhibited in plants with $\mathrm{K}^{+}$supplementation.

\section{References}

Adler, G., E. Blumwald and D. Bar-Zvi, 2010. The sugar beet gene encoding the sodium/proton exchanger 1 (BvNHX1) is regulated by a MYB transcription factor. Planta, 232: 187-195

Aebi, H., 1984. Catalase in vitro. Method Enzymol., 105: 121-126

Ashraf, M., 2009. Biotechnological approach of improving plant salt tolerance using antioxidants as marker. Biotechnol. Adv., 27: 84-93

Assaha, D.V.M., L. Liu, A.M.M. Mekawy, A. Ueda, T. Nagaoka and H. Saneoka, 2015. Effect of salt stress on Na accumulation, antioxidant enzyme activities and activity of cell wall peroxidase of huckleberry (Solanum scabrum) and eggplant (Solanum melongena). Int. J. Agric. Biol., 17: 1149-1156

Blumwald, E. and R.J. Poole, 1987. Salt tolerance in suspension cultures of sugar beet-induction of $\mathrm{Na}^{+} / \mathrm{H}^{+}$antiport activity at the tonoplast by growth in salt. Plant Physiol., 83: 884-887

Bor, M., F. Özdemir and I. Türkan, 2003. The effects of salt stress on lipid peroxidation and antioxidants in leaves of sugar beet Beta vulgaaris L. and wild beet Beta maritime L. Plant Sci., 164: 77-84

Brown, P.H., N. Bellaloui, M.A. Wimmer, E.S. Bassil, J. Ruiz, H. Hu, H. Pfeffer, F. Dannel and V. Römheld, 2002. Boron in plant biology. Plant Biol., 4: 205-223

Bui, E., 2013. Possible role of soil alkalinity in plant breeding for salttolerance. Biol. Lett., 9, 20130566

Cavalcanti, F.R., J.T.A. Oliveira, A.S. Martins-Miranda, R.A. Viégas and J.A.G. Silveira, 2004. Superoxide dismutase, catalase and peroxidase activities do not confer protection against oxidative damage in saltstressed cowpea leaves. New Phytol., 163: 563-571
Chérel, I., C. Lefoulon, M. Boeglin and H. Sentenac, 2014. Molecular mechanism involved in plant adaptation to low $\mathrm{K}^{+}$availability. $J$. Exp. Bot., 65: 833-848

Colla, G., Y. Rouphael, M. Cardarelli, A. Salerno and E. Rea, 2010. The effectiveness of grafting to improve alkalinity tolerance in watermelon. Environ. Exp. Bot., 68: 283-291

Degl'Innocenti, E., C. Hafsi, L. Guidi and F. Navari-Izzo, 2009. The effect of salinity on photosynthetic activity in potassium-deficiency barley species. J. Plant Physiol., 166: 1968-1981

Demidchik, V., S.N. Shabala, K.B. Coutts, M.A. Tester and J.M Davies, 2003. Free oxygen radicals regulate plasma membrane $\mathrm{Ca}^{2+}$ - and $\mathrm{K}^{+}$-permeable channels in plant root cells. J. Cell Sci., 116: 81-88

Demidchik, V., S.N. Shabala and J.M. Davies, 2007. Spatial variation in $\mathrm{H}_{2} \mathrm{O}_{2}$ response of Arabidosis thaliana root epidermal $\mathrm{Ca}^{2+}$ flux and plasma membrane $\mathrm{Ca}^{2+}$ channels. Plant J., 49: 377-386

Draper, H.H. and M. Hadley, 1990. Malondialdehyde determination as index of lipid peroxidation. Method Enzymol., 186: 421-431

EI-Sheikh, A.M., A. Ulrich and T.C. Broyer, 1967. Sodium and Rubidium as possible nutrients for sugar beet plants. Plant Physiol., 42: 12021208

Emi, K., M. Yamada and H. Fujiyama, 2015. Sodium, but not potassium, enhances root to leaf nitrate translocation in Swiss chard (Beta vulgaris var.cicla L.). Environ. Exp. Bot., 112: 27-32

Foyer, C.H. and B. Halliwell, 1976. The presence of glutathione and glutathione reductase in chloroplasts: a proposed role in ascorbic acid metabolism. Planta, 133: 21-25

Gill, S.S. and N. Tuteja, 2010. Reactive oxygen species and antioxidant machinery in abiotic stress tolerance in crop plants. Plant Physiol. Bioch., 48: 909-930

Gong, X., L. Chao, M. Zhou, M. Hong, L. Luo, L. Wang, W. Ying, J. Cai, S. Gong and F. Hong, 2011. Oxidative damages of maize seedlings caused by exposure to a combination of potassium deficiency and salt stress. Plant Soil, 340: 443-452

Hafsi, C., M.C. Romero-Puertas, L.A. del Rio, L.M. Sandalio and C. Abdelly, 2010. Differential antioxidative response in barley leaves subjected to the interactive effects of salinity and potassium deprivation. Plant Soil, 334: 449-460

Hänsch, R. and R.R. Mendel, 2009. Physiological functions of mineral micronutrients $(\mathrm{Cu}, \mathrm{Zn}, \mathrm{Mn}, \mathrm{Fe}, \mathrm{Ni}, \mathrm{Mo}, \mathrm{B}, \mathrm{Cl})$. Curr. Opin. Plant Biol., 12: 259-266

Hernandez, M., N. Fernandez-Garcia, J. Garcia-Garma, J.S. Rubio-Asensio, F. Rubio and E. Olmos, 2012. Potassium starvation induces oxidative stress in Solanum lycopersicum L. roots. J. Plant Physiol., 169: 1366-1374

Kanai, S., R.E. Moghaieb, H.A. EI-Shemy, R. Panigrahi, P.K. Mohapatra, J. Ito, N.T. Nguyen, H. Saneoka and K. Fujita, 2011. Potassium deficiency affects water status and photosynthetic rate of the vegetative sink in green house tomato prior to its effects on source activity. Plant Sci., 180: 368-374

Kehrer, J.P., 2000. The Haber-Weiss reaction and mehanisms of toxicity. Toxicology, 2000: 43-50

Koca, H., M. Bor, F. Özdemir and I. Türkan, 2007. The effect of salinity stress on lipid peroxidation, antioxidative enzymes and proline content of sesame cultivars. Environ. Exp. Bot., 60: 344-351

Kusaka, M., M. Ohta and T. Fujimura, 2005. Contribution of inorganic components to osmotic adjustment and leaf folding for drought tolerance in pearl millet. Physiol. Plant., 125: 474-489

Liu, L., A. Ueda and H. Saneoka, 2013. Physiological responses of white Swiss chard (Beta vulgaris L. subsp. cicla) to saline and alkaline stresses. Aust. J. Crop Sci., 7: 1046-1052

Lyubimova, L.N., Y.I. Pankova and L.F. Pestov, 2009. Amelioration of alkali (sodic/solonetz) soils. In: Agricultural Land Improvement' Amelioration and Reclamation, Vol. 2, pp: 241-266. Maslov, B.S (ed.). Encyclopedia of Life Support System

Maathuis, F.J.M., 2009. Physiological functions of mineral macronutrients Curr. Opin. Plant Biol., 12: 250-258

Maynard, D.N. and G.J. Hochmuth, 2007. Vegetables and vegetable industry, Knott's Handbook for Vegetable Growers, $5^{\text {th }}$ edition, pp: 1 53. Wiley, Hoboken, New Jersey, USA 
Ming, D.F., Z.F. Pei, M.S. Naeem, H.J. Gong and W.J. Zhou, 2012. Silicon alleviates PEG-induced water-deficit stress in upland rice seedlings by enhancing osmotic adjustment. J. Agron. Crop Sci., 198: 14-26

Nakano, Y. and K. Asada, 1981. Hydrogen peroxide is scavenged by ascorbate-specific peroxidases in spinach chloroplasts. Plant Cell Physiol., 22: 867-880

Nishiuchi, S., K. Fujihara, S. Liu and T. Takano, 2010. Analysis of expressed sequence tags from a $\mathrm{NaHCO}_{3}$-treated alkali-tolerant plant, Chloris virgata. Plant Physiol. Biochem., 48: 247-255

Pi, Z., P. Stevanato, L.H. Yv, G. Geng, X.L. Guo, Y. Yang, C.X. Peng and X.S. Kong, 2014. Effects of potassium deficiency and replacement of potassium by sodium on sugar beet plants. Russ. J. Plant Physiol., 61: 224-230

Pyo, Y.H., T.C. Lee, L. Logendra and R. Rosen, 2004. Antioxidant activity and phenolic compounds of Swiss chard (Beta vulgaris subspecies cycla) extracts. Food Chem., 85: 19-26

Qu, C., C. Liu, X. Gong, C. Li, M. Hong, L. Wang and F. Hong, 2012. Impairment of maize seedling photosynthesis caused by a combination of potassium deficiency and salt stress. Environ. Exp. Bot., 75: 134-141

Rodríguez-Navarro, and A., F. Rubio, 2006. High-affinity potassium and sodium transport systems in plants. J. Exp. Bot., 57: 1149-1160

Sacan, O. and R. Yanardag, 2010. Antioxidant and antiacetylcholinesterase activities of chard (Beta vulgaris L. var. cicla). Food Chem. Toxicol., 48: $1275-1280$

Saneoka, H., C. Nagasaka, D.T. Hahn, W.J. Yang, G.S. Premachandra, R.J. Joly and D. Rhodes, 1995. Salt tolerance of glycinebetaine-deficient and -containing maize lines. Plant Physiol., 107: 631-638

Saneoka, H., K. Shiota, H. Kurban, M.I. Chaudhary, G.S. Premachandra and K. Fujita, 1999. Effect of salinity on growth and solute accumulation in two wheat lines differing in salt tolerance. Soil Sci. Plant Nutr., 45: $873-880$

Shabala, S.N., 2009. Salinity and programmed cell death: unraveling mechanisms for ion specific signaling. J. Exp. Bot., 60: 709-712

Shabala, S. and T. Cuin, 2007. Potassium transport and plant salt tolerance. Physiol. Plant., 133: 651-669

Shin, R., R.H. Berg and D.P. Schachtman, 2005. Reactive oxygen species and root hairs in Arabidopsis root response to nitrogen, phosphorus and potassium deficiency. Plant Cell Physiol., 46: 1350-1357

Subbarao, G.V., O. Ito, W.L. Berry and R.M. Wheeler, 2003. Sodium: a functional plant nutrient. Crit. Rev. Plant Sci., 22: 391-416

Subbarao, G.V., R.M. Wheeler, G.W. Stutte and L.H. Levine, 2000. Low potassium enhances sodium uptake in red-beet under moderate saline conditions. J. Plant Nutr., 23: 1449-1470
Teakle, N.L. and S.D. Tyerman, 2010. Mechanisms of $\mathrm{Cl}^{-}$transport contributing to salt tolerance. Plant Cell Environ., 33: 566-589

Turner, N.C., 1981. Technique and experimental approaches for the measurement of plant water status. Plant Soil, 58: 339-366

Velarde-Buendía, A., S. Shabala, M. Cvikrova, O. Dobrovinskaya and I. Pottosin, 2012. Salt-sensitive and salt-tolerant barley varieties differ in the extent of potentiation of the ROS-induced $\mathrm{K}^{+}$efflux by polyamines. Plant Physiol. Bioch., 61: 18-23

Velikova, V., I. Yordanov and A. Edreva, 2000. Oxidative stress and some antioxidant systems in acid rain-treated bean plants. Plant Sci., 151: $59-66$

Wakeel, A., F. Abd-El-Motagally, D. Steffens and S. Schubert, 2009. Sodium-induced calcium deficiency in sugar beet during substitution of potassium by sodium. J. Plant Nutr. Soil Sci., 172: 254-260

Wakeel, A., M. Farooq, M. Qadir and S. Schubert, 2011. Potassium substitution by sodium in plants. Crit. Rev. Plant Sci., 30: 401-413

Wakeel, A., D. Steffens and S. Schubert, 2010. Potassium substitution by sodium in sugar beet (Beta vulgaris) nutrition on K-fixing soils. $J$. Plant Nutr. Soil Sci., 173: 127-134

Wang, Y. and W.H. Wu, 2010. Plant sensing and signaling in response to $\mathrm{K}^{+}$ deficiency. Mol. Plant, 3: 280-287

Welbaum, G.E., 2015. Chapter 17 Family Amaranthaceae, subfamily Chenopodiaceae. In: Vegetable Production and Practices, pp: 349 368. CPI Group Ltd., London, UK

White, P.J. and P.H. Brown, 2010. Plant nutrition for sustainable development and global health. Ann. Bot-London, 105: 1071-1080

Wu, Y.Y. and D.K. Xing, 2012. Effect of bicarbonate treatment on photosynthetic assimilation of inorganic carbon in two plant species of Moraceae. Photosynthetica, 50: 587-594

Xia, T., M.P. Apse, G.S. Aharon and E. Blumwal, 2002. Identification and characterization of a NaCl-inducible vacuolar $\mathrm{Na}^{+} / \mathrm{H}^{+}$antiporter in Beta vulgaris. Physiol. Plant., 116: 206-212

Zepeda-Jazo, I., A.M. Velarde-Buendía, R. Enríquez-Figueroa, J. Bose, S. Shabala, J. Muñiz-Murguía and I.I. Pottosin, 2011. Polyamines interact with hydroxyl radicals in activating $\mathrm{Ca}^{2+}$ and $\mathrm{K}^{+}$transport across the root epidermal plasma membranes. Plant Physiol., 157: 2167-2180

Zhu, J.K., 2001. Plant salt tolerance. Trends Plant Sci., 6: 66-71

(Received 06 September 2016; Accepted 07 November 2016) 